\title{
MOLECULAR VARIATION \\ OF ANTARCTIC GRASS DESCHAMPSIA ANTARCTICA DESV. FROM KING GEORGE ISLAND (ANTARCTICA)
}

\author{
KATARzyna J. Chwedorzewska ${ }^{1,2}$, Piotr T. BEDNAREK ${ }^{3}$, Jerzy PuChalsKi ${ }^{2}$ \\ ${ }^{1}$ Department of Antarctic Biology, Polish Academy of Sciences \\ Ustrzycka 10/12, 02-141 Warszawa, Poland \\ ${ }^{2}$ Botanical Garden - Centre for Biological Diversity Conservation \\ Polish Academy of Sciences \\ Prawdziwka 2, 02-973 Warszawa, Poland \\ e-mail: tmol.ob.@ihar.edu.pl \\ ${ }^{3}$ Plant Breeding and Acclimatization Institute \\ 05-870 Warszawa-Radzików, Poland
}

(Received: May 15, 2003. Accepted: November 25, 2003)

\begin{abstract}
Deschampsia antarctica Desv. plants collected on King George Islands (Antarctica) at two localities that differ in topographic and nutrition conditions exhibited morphological variation that differentiated plants of both locations. The molecular variation characteristic to individuals of both sites was tested using AFLP approach in order to verify whether morphological variation characteristic to the plants resulted from environmental factors or possibly from differences at the DNA level. Four primer pair combinations were used to generate 339 AFLP fragments, 132 of which were polymorphic and allowed evaluation of genetic relationships among $D$. antarctica individuals. Chi-square test revealed that only 12 signals were discriminative for the plants from both locations. Cluster analysis conducted on these AFLP fragments demonstrated that plants from the location rich in biogenes were more polymorphic than those from poor one. Our data suggest that the phenotypic variation specific to plants of both locations seem to be the result of adaptation to the environmental conditions like soil and moisture rather than reflect genetic differences.
\end{abstract}

KEY WORDS: Deschampsia antarctica, AFLP, genetic variation, Antarctic.

\section{INTRODUCTION}

Genus Deschampsia is cosmopolitan and widely dispersed around the globe, ranging from the polar circle to equator (in this area rather mountain summits) (Index Kewensis 1997). A high tolerance of adverse environmental conditions allows Deschampsia to colonize and dominate plots of land that are uninhabited by other plants (Nkongolo et al. 2001). A number of them, for example D. alba, D. arctica, D. nubigena and of course $D$. antarctica, inhabit extreme, harsh polar environments (Index Kewensis 1997). Moreover, Deschampsia antarctica is one of only two native vascular plants successfully colonising the Antarctic during the past 10000 years (Lewis-Smith 2001). The second one is Colobanthus quitensis. Only one alien vascular plant species Poa annua has been successfully introduced to Antarctica, but seems to have a minor distribution and influence on Antarctic ecosystem (Olech 1996; Frenot et al. 1999).
$D$. antarctica is a biperennial grass distributed continuously from $68^{\circ} 43^{\prime}$ to $67^{\circ} 32^{\prime} \mathrm{W}$ alongside the Antarctic coast reaching its greatest abundance at Lynch Island, South Orkney Islands, South Shetland Islands and South Sandwich Islands (Laws 1984). It occupies different habitats from wet to dry and from high to poor nutrient, exhibiting some differences like leaves colour, culm length, inflorescence production and maturation (Corner 1971). D. antarctica forms very tight, typical for polar conditions tussocks (Day et al. 1999), most probably developed to trap and store solar radiation (Komarkova 1985) and exhibits a high level of photosynthetic capacity at subzero temperatures (Alberdi et al. 2002) and respiration activity down to $-10^{\circ} \mathrm{C}$ (Edwards and Lewis Smith 1988; Laws 1984; Bystrzejewska 2001). It has been suggested that the unusually high level of accumulation of sucrose and fructans may be responsible for its resistance to freezing (Zuniga et al. 1996, 2001). The other extrordinary trait characteristic to $D$. anatarctica is its resistance to light stress (Alberdi et al. 2002). 
Resent observations carried out in the vicinty of the Arctowski Station allowed identification of two separated by distance and glacier sites of $D$. antarctica. The plants are growing in distinct soil conditions and form densed paches with many plants at the reach soil (site under penguine rookery) and growing as individual scattered plants at the site with poor soil (site at the Demay Point). It was demonstrated (Nędzarek, unpublished data) that the concentration of the biogenes determined in the water flow at the site near penguine rockery in comparison to that over glacier was very high. Nędzarek identified $14.53 \mathrm{mg} / \mathrm{dm}^{3}$ of inorganic nitrogen $\left(\mathrm{N}_{-} \mathrm{NH}_{4}{ }^{+}, \mathrm{N}_{-} \mathrm{NO}_{3}{ }^{-}\right.$and $\left.\mathrm{N}_{-} \mathrm{NO}_{2}{ }^{-}\right)$and $12.25 \mathrm{mg} / \mathrm{dm}^{3}$ of phosphorous ( $\mathrm{P}-\mathrm{PO}_{3}{ }^{3-}$ ) and $\mathrm{Cl}^{-} 350 \mathrm{mg} / \mathrm{dm}^{3}$ in first and $0.33,0.066$ and $25 \mathrm{mg} / \mathrm{dm}^{3}$ of the appropriate ions respectively in the former site. Since the soil surface temperature in this region calculated from the years 1979-1983, 1986$-1987,1991-1993,1996-1998$ ranged between $-0.1^{\circ} \mathrm{C}$ and $-2.0^{\circ} \mathrm{C}$, with the mean annual temperature of $-0.5^{\circ} \mathrm{C}$ (Zwolska and Rakusa-Suszczewski 2002) and were similar for both localities, the observed variation (also morphological) could be attributed to environmental conditions, but molecular studies are needed to exclude genetic factors.

To our best knowledge, little was done to study this genus at the molecular level using DNA fingerprinting. The data are limited to RAPD studies on genetic variability between Deschampsia cespitosa populations collected from heavy metal contaminated and uncontaminated sites in Northern Ontario (Nkongolo et al. 2001). Although (Nkongolo et al. 2001) most of the identified differences were attributed to interpopulation variability, some markers characteristic to each population were also evaluated. Unfortunately, no molecular studies on $D$. antarctica are available.

The Amplified Fragment Length Polymorphism (AFLP) (Vos et al. 1995) technique that generates highly reproducible results with many polymorphisms visualized on a single gel could be used in this case. So far, among others it has been successfully applied to construct dense linkage maps (Becker et al. 1995) or for mapping a single locus (Voort et al. 1997). It has also been efficient in taxonomic studies in estimating genetic relationship in lentil (Sharma et al. 1996), soybean (Maughan et al. 1993) bermudagrass (Zhang et al. 1999) or even in clustering Elymus repens individuals differing in morphology (Szczepaniak et al. 2002).

The aim of the study was to analyse variation based on AFLP fingerprints generated on individual plants of $D$. antarctica collected from two localities that differed in topography and nutrition conditions. We wanted to verify whether the plants growing at different soil conditions and exhibiting morphological differences also reflect any variation at the molecular level.

\section{MATERIAL AND METHODS}

\section{Plant Sampling}

During the antarctic summer 2000/2001, samples of D. antarctica were collected on west shore of Admiralty Bay in the vicinity of Arctowski Station at the area of SSSI no. 8 (King George Island, South Shetlands Islands). The site at penguin rookery consisted of many patches that spread on approximately one square meter and included hardly distinguishable individuals. They were located under a pen- guin rookery on the north-facing rocky slope lat. $62^{\circ} 09^{\prime} 30^{\prime}$ 'S , long. $58^{\circ} 28^{\prime} 30^{\prime}$ ' $\mathrm{W}$. The site was very moist, flushed by melt water with very high nutrient concentration (Nędzarek, data unpublished). The site at Demay Point consisting of 21 individual plants was located far from bird colonies and gathering places of large mammals (about two kilometres) on rocky knolls on the top of Demay Point lat. $61^{\circ} 11^{\prime} 15^{\prime}$ 'S , long. 58 $27^{\prime} 30^{\prime}$ 'W. At least two leaves from all individuals of $D$. antarctica inhabiting these sites were collected without making serious damage to plants. The collected plants within each site were separated by approximately 20 meters. Leaves were washed in ether, dried on Whatman $3 \mathrm{MM}$ paper, and stored at $-20^{\circ} \mathrm{C}$.

\section{DNA Extraction}

Total genomic DNA was extracted from approximately $100 \mathrm{mg}$ of dry leaf tissue following the procedure suggested by the manufacturer of the DNeasy Plant Mini Kit (Qiagen). DNA integrity was analysed electrophoretically in $1.4 \%$ agarose gel containing $1 \times \mathrm{TBE}$ buffer and ethidium bromide $(0.5 \mu \mathrm{g} / \mathrm{ml})$ under $20 \mathrm{~V} / \mathrm{cm}$. The quantity was determined spectrophotometrically (GeneQuanta, Pharmacia LKB). For routine works standard dilutions 10 $\mu \mathrm{g} / \mathrm{ml}$ were used.

\section{Amplified Fragment Length Polymorphism (AFLP)}

The AFLP technique was performed according to the procedure described by Vos et al. (1995) with minor modifications (Bednarek et al. 1999). The digestion step was carried out in $10 \mu \mathrm{l}$ for 210 minutes at $37^{\circ} \mathrm{C}$. The reaction mixture consisted of $0.5 \mu \mathrm{g}$ of genomic DNA, $10 \mathrm{U}$ of EcoRI, 3U of MseI (New England Biolabs) in $1 \times$ ligation buffer (New England Biolabs) containing $50 \mathrm{mM} \mathrm{NaCl}$ and 5 $\mu \mathrm{g}$ BSA. The enzymes were inactivated for $15 \mathrm{~min}$ at $70^{\circ} \mathrm{C}$ following ligation of the heteroduplexes called adapters (Table 1) to the sticky ends of the digested DNAs. This step was carried out in $25 \mu \mathrm{l}$ at $37^{\circ} \mathrm{C}$ for $3 \mathrm{~h}$. The ligation mixture consisted of $10 \mu \mathrm{l}$ of the digested sample, to which 5 pmol of EcoRI and $50 \mathrm{pmol}$ of MseI adaptors, $1 \mathrm{U}$ of T4 DNA ligase, in $50 \mathrm{mM} \mathrm{NaCl}, 12.5 \mu \mathrm{g}$ BSA, $1 \times$ ligation buffer (New England Biolabs) were added. The products were diluted in $1 \times$ TE buffer (1:6). This was followed by a pre-selective amplification step in a total volume of 25 $\mu \mathrm{l}$. The reaction mixture consisted of $2.5 \mu \mathrm{l}$ of the $1: 6 \mathrm{dilu}-$ ted template, $1 \times \mathrm{PCR}$ buffer, $2.5 \mathrm{mM} \mathrm{MgCl}_{2}, 0.4 \mathrm{mM}$ dNTPs, $1 \mathrm{U}$ Taq DNA polimerase (Qiagen) and $12 \mathrm{pM}$ of each pre-selective primer (Table 1) using the following temperature profile: $\left[94^{\circ} \mathrm{C}-30 " ; 56^{\circ} \mathrm{C}-60 \text { '; } 72^{\circ} \mathrm{C}-60^{\prime \prime}\right]_{19}$;

TABLE 1. Adapter and primer sequences.

\begin{tabular}{ll}
\hline Adapter/Primer & Sequence $\left(5^{\prime} \rightarrow 3^{\prime}\right)$ \\
\hline Adapter EcoRI & CTCGTAGACTGCGTACC \\
Adapter MseI & CATCTGACGCATGGTTAA \\
& TACTCAGGACTCATA \\
EcoRI preselective primer & GAGTCCTGAGTAGCAG \\
MseI preselective primer & GACTGCGTACCAATTCA \\
E-Azz - selective primer & GACTGCGTACCAATTCAzz \\
M-Cyy - selective primer & GATGAGTCCTGAGTAACyy \\
\hline
\end{tabular}

$\mathrm{E}$ and $\mathrm{M}$ state for any selective primer complementary to EcoRI and MseI adaptors respectively; -zz, -yy - any combination of the nucleotides at the primers 3'ends 


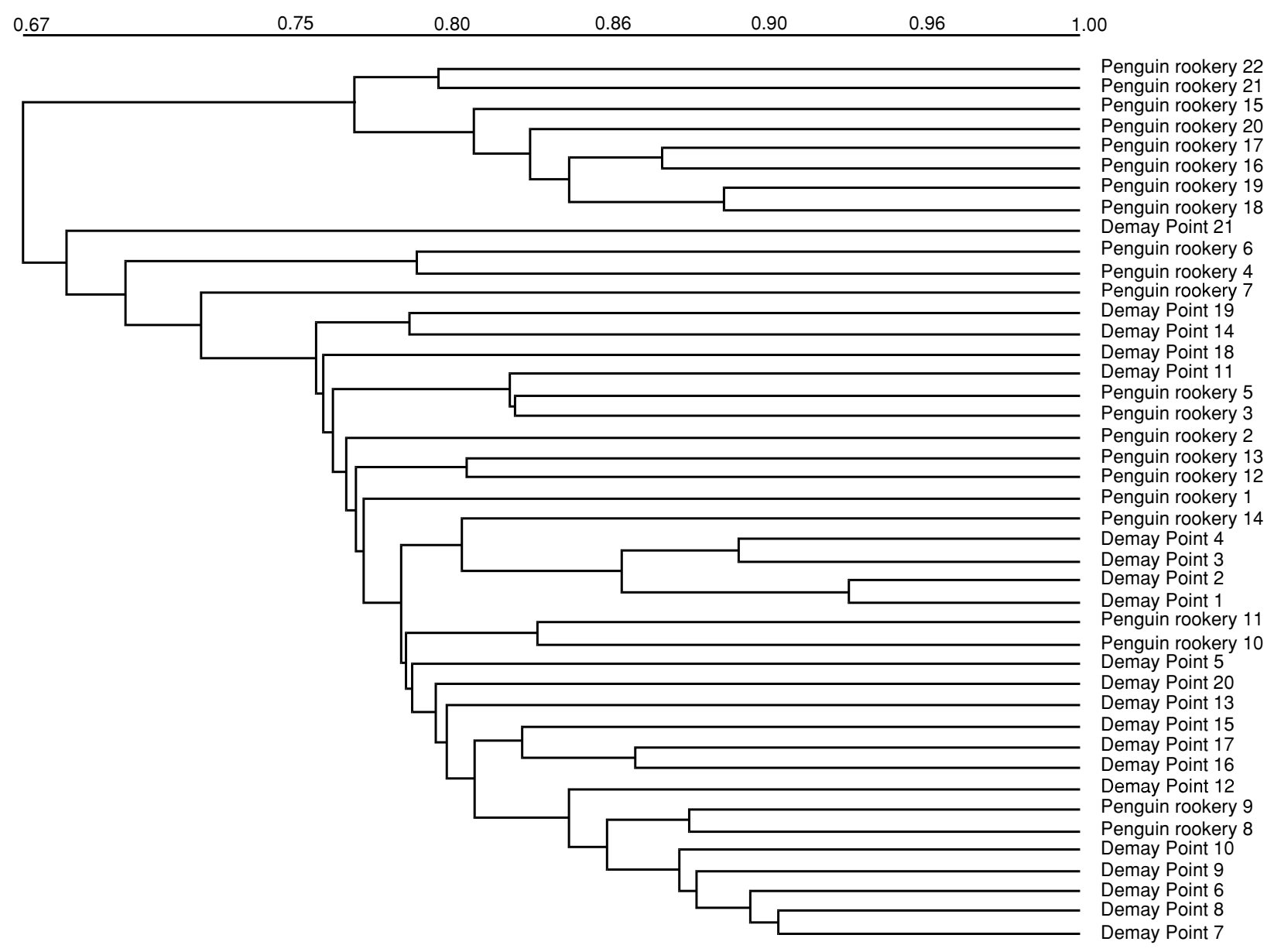

Fig. 1. Dendrogram based of all polimorphic fragments for all individuals from Penguin rookery and Demay Point.

[72 $\left.{ }^{\circ} \mathrm{C}-300^{\prime} '\right]$. Amplification products were diluted in $1 \times \mathrm{TE}$ (1:20). The samples were processed according to a selective PCR cycling programme: $\left[94^{\circ} \mathrm{C}-4^{\prime}\right]\left[94^{\circ} \mathrm{C}-30^{\prime}\right.$; $65^{\circ} \mathrm{C}$ ramp-0. $\left.7^{\circ} \mathrm{C}-30^{\prime \prime} ; 72^{\circ} \mathrm{C}-60^{\prime \prime}\right]_{13}\left[94^{\circ} \mathrm{C}-30 " ; 56^{\circ} \mathrm{C}-30 "\right.$; $\left.72^{\circ} \mathrm{C}-60^{\prime \prime}\right]_{25}\left[72^{\circ} \mathrm{C}-600^{\prime \prime}\right]\left[5^{\circ} \mathrm{C}\right]$. The reactions were running

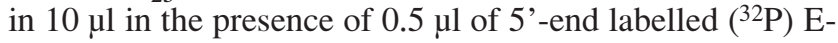
$\mathrm{XYZ}$ (labelling reactions were performed in $50 \mu \mathrm{l}$ in T4 polunucleotide kinase buffer, containing $100 \mu \mathrm{Ci} \gamma-\left({ }^{32} \mathrm{P}\right)$ rATP, $10 \mathrm{U} \mathrm{T} 4$ polynucleotide kinase at $37^{\circ} \mathrm{C}$ for $60 \mathrm{~min}$ ), $0.5 \mu \mathrm{l}(50 \mathrm{pM})$ of unlabelled M-XYZ selective primers, 1.5 $\mu \mathrm{l}$ of the 1:20 diluted template, in $1 \times \mathrm{PCR}$ buffer, $2.5 \mathrm{mM}$ $\mathrm{MgCl}_{2}, 0.4 \mathrm{mM}$ dNTP and $0.02 \mathrm{U}$ of HotStarTaq DNA polimerase. The PCR products were denaturated at $90^{\circ} \mathrm{C}$ for 5 minutes following immediate cooling on ice in the presence of $6 \mu \mathrm{l}$ of the denaturating dye $(80 \%$ formamide, $10 \mathrm{mM}$ EDTA, $0.05 \%$ bromophenol blue and $0.05 \%$ xylene cyanol). Aliquots $(6 \mu \mathrm{l})$ of sample solution were loaded onto denaturating 5\% polyacrylamide gel (Sambrook et al. 1989). After electrophoretic separation gel was exposed to $\mathrm{X}$-ray film (FOTON XC), for 24-48 h.

\section{Identification of the primer combinations}

To identify selective primers used in the AFLP technique that generate reproducible and easily scorable fingerprints on $D$. antarctica templates the following seventeen primer pairs combinations were tested (E-AAA/M-CAA; E-
-AAA/M-CAC; E-AAA/M-CCA; E-AAA/M-CCC; E-AAC/M-CAA; E-AAC/M-CAT; E-AAC/M-CCA; E-AAC/M-CCC; E-AGG/M-CAA; E-AGG/M-CAG; E-AGG/M-CAT; E-AGG/M-CCG; E-AGG/M-CCC; E-AGT/M-CAG; E-AGT/M-CAT; E-AGT/M-CTA; E-AGT/M-CTT). Six DNA templates were used.

\section{Data analysis}

Visible, reproducible and polymorphic fragments were scored as presence (1) and absence (0) and arranged in a form of matrix for further evaluation. The similarity between AFLP fragments differentiating plants representing penguin rookery and Demay Point with respect to their frequency distribution was checked with the chi-square test with one degree of freedom at a significance level of 0.05. The AFLP signals with a chi-square greater or equal to the critical value, or/and those that were polymorphic for the plants from both sites were used to construct similarity matrixes.

\section{Clustering}

The estimates of similarity were based on Dice coefficients (1945) and clustering was performed using unweighted pairgroup with arithmetic averages (UPGMA) clustering method (Sokal and Michener 1958; Saiotu and Nei 1986). The results were presented in form of dendrogrames (Figs 1 and 2). 


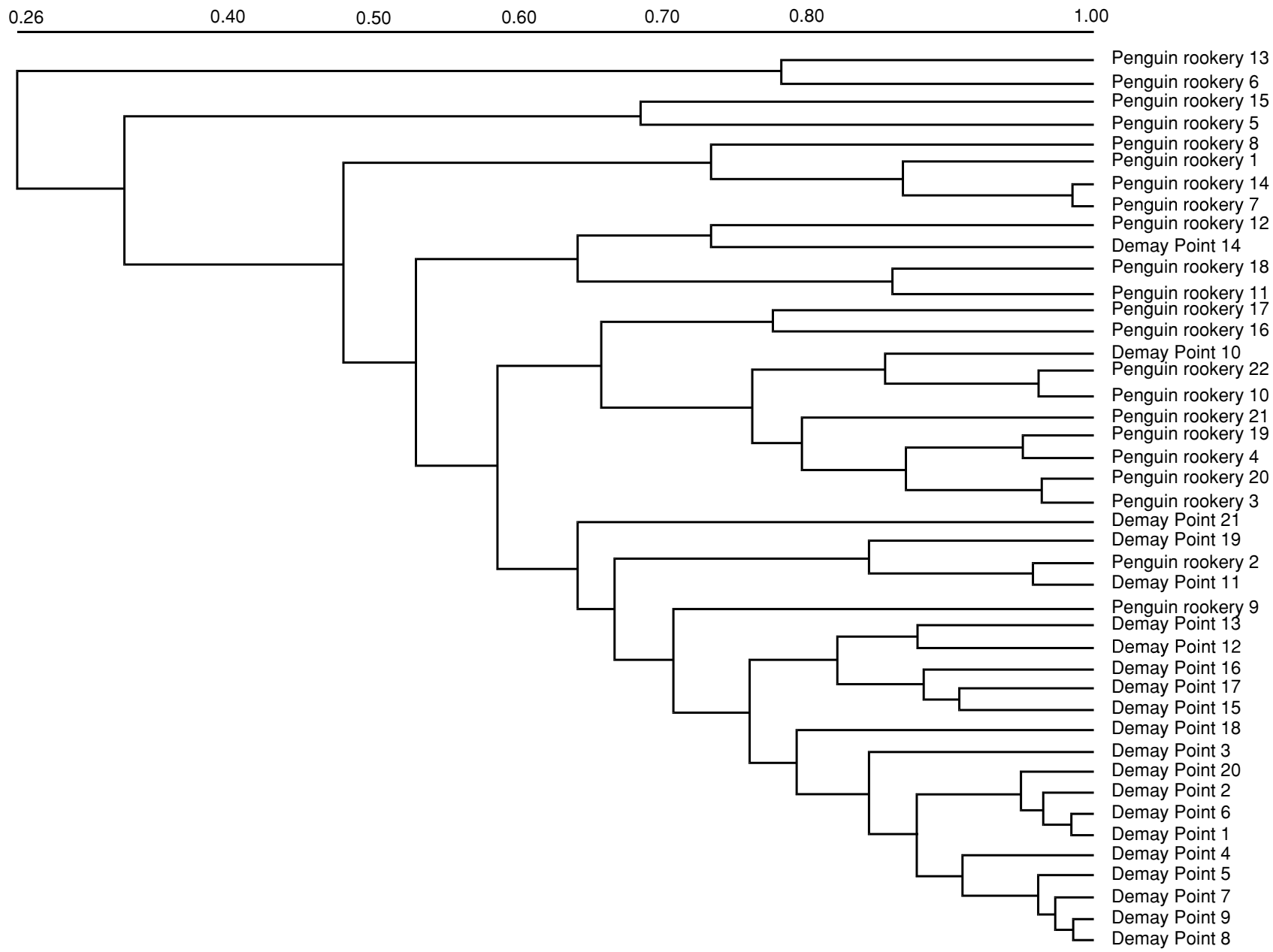

Fig. 2. Dendrogram based on AFLPs that according to chi-square test differentiate both samples.

\section{RESULTS}

\section{Field observations}

D. antarctica located on King George Island grows in large amounts in the vicinity of penguine colonies and a gathering place of large mammals along the ice-free coast of Admiralty Bay, sometimes forming uninterrupted grass areas. At the highest sites, far from animal colonies, the grass occurred as individual tufts scattered over a fairly wide area. $D$. antarctica inhabits even high sea cliffs, which sometimes have restricted areas of flat ground in front of them. In some places forms paches among which occur cushions of Colobanthus quitensis or accessories of mosses or lichens.

Probably the most evident morphological variability was observed in case of plants that grew at different soil conditions. Two locations that were approximately $6 \mathrm{~km}$ apart and separated topologically by icefalls and glacier were selected. The individuals from rich soil formed dense tuffs and grew as uninterrupted big patches (varying form 0.4$-1.5 \mathrm{~m}^{2}$ ), revealing good tolerance to direct contact with animal feces. The plants in this habitats were green, robust, had well-developed foliage and erect culms. D. antarctica from the other site, located over the icefalls and glacier only occasionally grew as scattered single plants and was mainly restricted to cracks between the rocks. The plants were much smaller, olive-green in colour with some brown dead leaves and formed small single flat individual tufts, that varied from 4 to $12 \mathrm{~cm}$ in diameter.

\section{AFLP}

Out of seventeen primer combinations used in the experiment the E-AGT/M-CAG one gave no molecular patterns, E-AGT/MCTA amplified only four fragments and E-AAC/M-CAA, E-AGG/M-CCA, E-AGG/M-CCC, E-AGT/M-CAT resulted in fingerprints of insufficient quality and thus, were eliminated from further analysis. The remaining combinations generated clearly distinguishable, individual fingerprints. The E-AAA/M-CAA, E-AAA/M-CAC, E-AGG/M-CCG, E-AGG/M-CAG combinations amplified the highest number of DNA fragments (Table 2) visualized on PAGE and were selected for further studies.

In total, these combinations amplified 339 fragments that were generated on 21 and 22 DNA templates isolated and processed according to the AFLP approach from plants collected at penguin rookery and Demay Point. The number of the DNA fragments generated by individual primer pair varied from 74 to 92 with an average of 85 . All primer pairs generated polymorphic signals and their number ranged between 24 and 40 . Nearly $40 \%$ of the identified DNA fragments exhibited polymorphisms (Table 2). Out of 132 fragments polimorphic between plants from both sites twe- 
TABLE 2. Arrangement of data generated with the selected primer pairs.

\begin{tabular}{lccc}
\hline Primer pair code & $\begin{array}{c}\text { Detected } \\
\text { fragments (in total) }\end{array}$ & $\begin{array}{c}\text { Polymorphic } \\
\text { fragments }\end{array}$ & $\begin{array}{c}\% \text { of } \\
\text { polymorphisms }\end{array}$ \\
\hline E-AAA/M-CAA & 92 & 35 & 38 \\
E-AAA/M-CAC & 90 & 33 & 37 \\
E-AGG/M-CCG & 83 & 40 & 48 \\
E-AGG/M-CAG & 74 & 24 & 32 \\
\hline Total & 339 & 132 & 39 \\
\hline
\end{tabular}

TABLE 3. Frequencies of the AFLP fragments that differentiated (at $\mathrm{p}_{\mathrm{val}}=0.05$ ) plants collected at penguin rookery and Demay Point.

\begin{tabular}{lcccc}
\hline Primer code & $\begin{array}{c}\text { Band } \\
\text { number }\end{array}$ & $\begin{array}{c}\text { Band } \\
\text { frequency } \\
\text { (penguin } \\
\text { rookery) }\end{array}$ & $\begin{array}{c}\text { Band } \\
\text { frequency } \\
\text { (Demay } \\
\text { Point) }\end{array}$ & $\chi^{2}$ \\
\hline E-AAA/M-CAA & 17 & 0.048 & 0.272 & 0.0456 \\
& 20 & 0.286 & 0 & 0.0069 \\
& 45 & 0.952 & 0.318 & 0 \\
E-AAA/M-CAC & 46 & 0.762 & 0.227 & 0.0005 \\
& 8 & 0.905 & 0.591 & 0.0184 \\
E-AGG/M-CAG & 83 & 0.905 & 0.636 & 0.0373 \\
E-AGG/M-CCA & 80 & 0.286 & 0 & 0.0069 \\
& 26 & 0.286 & 0.636 & 0.0212 \\
& 33 & 0.905 & 0.591 & 0.0184 \\
& 42 & 0.905 & 0.636 & 0.0373 \\
& & 0.905 & 0.636 & 0.0373 \\
& & 0.190 & 0 & 0.0316
\end{tabular}

lve appeared to be discriminative for the localities as indicated by the chi-square test (Table 3). Although three of the fragments that were present at penguin rookery location were not identified among plants from Demay Point, but their frequency was relatively low (Table 3). The remaining discriminative signals were identified among plants from both localities and, except for one band (E-AAA/M-CAA-17), the appropriate polymorphisms occurred more often among individuals from penguin rookery. No DNA fragments missing at penguin rookery and present at Demay Point were detected.

\section{Cluster analysis}

Clustering of the results obtained, based on the total number of the polymorphic signals identified in plants from penguin rookery and Demay Point, revealed two clusters that were similar to each other in $71.4 \%$. The first cluster was formed of nine individuals collected exclusively from penguin rookery, the second one consisted of individuals from both localities. Although in the last case individuals of both locations were mixed with each other, they were not dispersed in random manner, and plants of the same location formed kind of blocks that were separated by rare individuals from the penguin rookery. Based on similarity estimates (data not shown), most plants from Demay Point were more similar to each other than those from penguin rookery. Genetic-similarity estimates among individuals from both localities varied from 48.9 to $92.7 \%$ (Fig. 1). Although individuals from different sites were mixed within the second cluster, it is evident that those from penguin rookery were mostly more similar than those from the first subcluster.

In general, the very similar results could be observed when only the DNA fragments discriminating plants of both sites were clustered. Although no separate groups could be identified, individuals from the penguin rookery were more distinct at the DNA level and predominantly occupied the outer part of the dendrogram, which represented most dissimilar individuals. The middle part of the dendrogram was occupied by individuals from both localities. Finally, the plants with the lowest level of variability $86.8 \%$ originated from the Demay Point could be seen within the inner part of the dendrogram (Fig. 2).

The comparison of both dendrograms demonstrates that the individuals from the penguin rookery exhibited more polymorphisms than those from Demay Point and occupied opposite parts of the dendrograms. Moreover, the individuals from Demay Point seem to be a narrow part of the plants from the penguin rookery.

\section{DISCUSSION}

The plants growing on the coastal area being in the vicinity of the penguin rookery and formed by the deposit of windborne aerosols (mainly sea water), in contrast to those from Demay Point, were strongly manured by birds (Rakusa-Suszczewski 1993; Juchnowicz-Bierbasz and RakusaSuszczewski 2002; Juchnowicz-Bierbasz 1999) and thus, had good soil conditions. The analysis the water flow (Nędzarek, unpublish data) demonstrated that nitrogen and phosphorous ions were present there in a very high concentration which was several magnitudes greater than in case of the plants from Demay Point. Moreover, the later inhabited higher areas, where the landscape resembled a polar desert with freshly weathered rock, mineral soil and glacial deposits almost devoid of vegetation (Tatur and Myrcha 1983, 1993). All these differences could cause the identified variation and if so, may demonstrate of plasticity of $D$. antarctica genome and ability of the plants to grow under extreme conditions. The other explanation, that could not be rejected, was that the individuals from both locations reflect any variation at the molecular level.

Previously, Corner (1971) revealed some morphological differences between $D$. antarctica plants growing under distinct moisture and nutrition conditions. Similarly, studies on subpopulations of $D$. antarctica, growing in the vicinity of Arctowski Station under different trophic and topographic conditions, conducted by Barcikowski et al. (1999) demonstrated that they differed in the maximum crop values (498.8 to $2232.1 \mathrm{~g}$ dry weight $\mathrm{DWm}^{-2}$ ), green biomass values (294.4 to $1256.6 \mathrm{~g} \mathrm{DWm}^{-2}$ ) and net annual production of the above-ground parts (294.4 to $1256.6 \mathrm{~g} \mathrm{DWm}^{-2}$ ). It was suggested, that the variation should be mostly attributed to the influence of the environment. However, the influence of the genetic background should not be excluded. Some prerequisites for that were given by Nkongolo et al. (2001), who studied isolated but morphologically identical populations of $D$. cespitosa, identified population-specific RAPD fragments. In our study we have also identified three AFLP fragments that were amplified exclusively on the penguin rookery plant templates. However, their frequency was low and we cannot exclude that they reflect a higher level of polymorphisms of these plants in comparison to those from Demay Point. This seems to be confirmed by the fact that most of the AFLP fragments that were discriminative were more abundant in case of plants from the 
penguin rookery. Since it was not our aim to assign any of these fragments to the phenotypic differences exhibited by plants from both locations and, to do that, special studies on segregating populations are needed, we are not sure what these differences reflect: genetic changes between plants of the locations or just alternation of the population structure. However, clustering data seem to indicate that the alternation or restriction of the genetic structure of the plant from Demay Point is the most probable explanation. This is supported by the fact that most individuals collected from the site located over the glacier were less variable at the DNA level and were grouped within the inner part of the dendrograms. It seems as though plants from Demay Point were a subpart of those from penguin rookery.

This result seems a bit surprising to us since both sites were separated by distance, height above sea level and glacier. Moreover, if one consider continuous wind direction then it is hardly difficult to understand that the migration could appear in this direction. However, we cannot exclude that some plants or seeds were transported to Demay Point by birds. If so, then it gets obvious, why the level of genetic variability identified by AFLP technique among individuals from Demay Point is lower than that from penguin rookery. Moreover, isolation of the plants from Demay Point may additionally result in reduction of the number of polymorphisms. This is especially the case if $D$. antarctica is an out-crossing species. Unfortunately, appropriate data are not available and the situation was not clarified by studies carried out by Żebrowski and Chwedorzewska, (unpublished data), who collected $D$. antarctica seeds along the coast of Admiralty Bay during the antarctic summer 2000/2001 and tested their viability. Even after special treatments (stratification, or plant hormone treatment) the seeds did not germinate. It seems to agree with Corner's (1971) observation that $D$. antarctica may not produce mature seed every year.

Summing up, we believe that the observed morphological variation between plants from penguin rookery and Demay Point seems to be the result of adaptation to the environmental conditions like soil and moisture rather, than reflect genetic differences. This seems to agree with Romero's et al. (1999) results suggesting that the leaves' anatomical features of $D$. antarctica do not correspond to genotypic adaptation to the harsh environmental Antarctic conditions, but rather to a plastic response of the phenotype to meliorated growth conditions in the laboratory. Moreover, we tend to think that the plant from Demay Point somehow migrated from penguin rookery and thus, based on clusteruing data are its narrow part. Finally, our results confirm the usability of the AFLP technique in studies on D. antarctica.

\section{LITERATURE CITED}

ALBERDI M., BRAVO L.A., GUTIERRWZ A., GIDEKEL M., CORCUERA L.J. 2001. Ecophisiology of Antarctic vascular plants. Phisiol. Plant. 115: 479-486.

BARCIKOWSKI A., ŁYŻWIŃSKA R., ZARZYCKI K. 1999. Growth rate and biomass production of Deschampsia antarctica Desv. in the Admiralty Bay region, South Shetland Islands, Antarctica. Polish Polar Res. 20: 301-311.

BECKER J., VOS P., KUIPER M., SALAMIMI F., HEUN M., 1995. Combined mapping of AFLP and RFLP markers in barley. Molec. Gen. Genet. 249: 65-73.
BEDNAREK P.T., CHWEDORZEWSKA K.J., KRÓLICZAK J., PUCHALSKI J., ZAWADA M. 1999. AFLP molecular markers as a tool for genetic variability studies of rye inbred lines. Biuletyn Instytutu Hodowli i Aklimatyzacji Roślin 211: 219-227. (in Polish)

BRAVO L.A., ULLOA N., ZUNIGA G.E., CASANOVA A., CORCUERA L.J., ALBERDI M. 2001.Cold resistance in Antarctic angiosperms. Phisiol. Plant. 111: 55-65.

BYSTRZEJEWSKA G. 2001. Photosynthetic temperature response of antarctic plant Deschampsia antarctica and of temperate region plant Deschampsia cespitosa. Pol. J. Ecol. 49: 215-219.

CORNER R.W.M. 1971. Studies in Colobanthus quitensis (Kunth) Bartl. and Deschampsia antarctica Desv.: IV. Distribution and reproductive performance in Argentine islands. Br. Antarctic Surv. Bull. 26: 41-50.

DAY T.A., RUHLAND C.T., GROBE C.W., XIONG F. 1999. Growth and reproduction of Antarctic vascular plants in response to warming and UV radiation reductions in the field. Oecologia 119: 24-35.

DICE L.R. 1945. Measures of the amount of ecologic association between species. Ecology 26: 297-302.

Donini P. Elias M.L., Bougourd S.M., Koebner R.M.D. 1997. AFLP fingerprinting reveals pattern differences between templates DNA extracted from different plant organs. Genome 40: 521-526.

EDWARDS J.A., LEWIS SMITH R.J. 1988. Photosynthesis and respiration of Colobanthus quitensis and Deschampsia antarctica from the maritime antarctic. Br. Antarctic Surv. Bull. 81: 43-63.

FRENOT Y., AUBRY M., MISSET M.T., GLOAGUEN J.C., GOURRET J.P., LEBOUVIER M. 1999. Phenotypic plasticity and genetic diversity in Poa апnи $\mathrm{L}$. (Poaceae) at Crozet and Kerguelen Islands (subantarctic). Polar Biol. 22: 302-310.

INDEX KEWENSIS ON COMPACT DISC, version 2.0. 1997. Royal Botanic Gardens Kew Oxford: Oxford University Press, CD-ROM.

JUCHNOWICZ-BIERBASZ M. 1999. Year-round changes of nutrients in fresh water bodies near Arctowski Station, South Shetland Island, Antarctica. Pol. Polar Res. 20: 243-258.

JUCHNOWICZ-BIERBASZ M., RAKUSA-SUSZCZEWSKI S. 2002. Nutrients and cations in soil solution from the present and relict penguin colonies (Admiralty Bay, King George Island). Pol. J. Ecol. 50: 79-91.

KOMARKOVA V., PONCET S., PONCET J. 1985. Two native antarctic vascular plants, Deschampsia antarctica and Colobanthus quitensis: a new southernmost locality and other localities in the antarctic peninsula area. Arctic and Alpine Res. 17: 401-416.

LAWS R.M. 1984. Antarctic Ecology. Br. Antarctic Surv. Cambridge, England 1: 820-830.

LEWIS-SMITH R.I. 2001. The enigma of Colobanthus quithensis and Deschampsia antarctica proceeding in SCAR 8th Biology Symposium "Antarctic Biology in a Global Context" Amsterdam Netherlands S5P31.

MAUGHAN P.J., SAGHAI MAROOF M.A., BUSS G.R., HUESTIS G.M. 1993. Amplified fragment length polymorphism (AFLP) in soybean: species diversity, inheritance, and nearisogenic line analysis. Theor. Appl. Genet. 93: 392-401.

NEI M., LI W.-H. 1979. Mathematical model for studing genetic variation in terms of restriction endonucleases. Proc. Natl. Acad. Sci. USA 76: 5269-5273.

NKONGOLO K.K., DECK A., MICHAEL P. 2001. Molecular and cytological analyses of Deschampsia cespitosa populations from Northern Ontario (Canada). Genome 44: 818-825.

OLECH M. 1996. Human impact on terrestrial ecosystems in west Antarctica. Proceeding NIPR Symposium of Polar Biology 9: 299-306.

RAKUSA-SUSZCZEWSKI S. 1993. Matter transport and budgets in the Admiralty Bay area. In: Rakusa-Suszczewski S. 
(ed.) The Maritime Antarctic coastal ecosystem of Admiralty Bay. Warsaw, Department Antarctic Biology, Polish Academy of Science, pp. 19-25.

ROMERO M., CASANOVA A., ITURRA G., REYES A., MONTENEGRO G., ALBERDI M. 1999. Leaf anatomy of Deschampsia antarctica (Poaceae) from the Maritime Antarctic and its plastic response to changes in the growth conditions. Revista Chilena de Historia Natural 72: 411-425.

SAIOTU N., NEI M. 1986. The number of nucleotides required determining the branching order of three species, with special reference to human - Chimpanzee-Gorilla divergence. J. Molec. Evol. 24: 189-204.

SAMBROOK J., FRITSCH E.F., MANIATIS T. 1989. Molecular

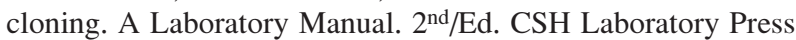
Cold Spring Harbor, New York.

SHARMA S.K., KNOX M.R., ELLIS T.H.N. 1996. AFLP analysis of the diversity and phylogeny of Lens and its comparison with RAPD analysis. Theor. Applied Genet. 93: 751-758.

SOKAL R.R., MICHENER C.D. 1958. A statistical method for evaluating systematic relationships. Univ. Kansas Sci. Bull. 38: 1409-1438.

SZCZEPANIAK M., CIEŚLAK E., BEDNAREK P.T. 2002. Morphological and AFLP variation of Elymus repens (L.) Gould (Poaceae). Cell. Mol. Biol. Let. 7: 547-558.

TATUR A., MYRCHA A. 1983. Ornithegenic soils. In: RakusaSuszczewski S. (ed.) The Maritime Antarctic coastal ecosy- stem of Admiralty Bay. Warsaw, Department of Antarctic Biology, Polish Academy of Science, pp. 161-165.

TATUR A., MYRCHA A. 1993. Ornithegenic soils on King George Island, South Shetland Islands (maritime Antarctic zone). Polar Biol. 5: 405-417.

VOORT J.R. VAN, WOLTERS P., FOLKERTSMA R., HUTTEN R., ZANDVOORT P. VAN, VINKE H., KANYUKA K., BENDAHMANE A., JACOBSEN E., JANSSEN R., BAKKER J. 1997. Mapping of the cyst nematode resistance locus Gpa2 in potato using a strategy based on comigrating AFLP markers. Theor. Appl. Genet. 95: 874-880.

VOS P., HOGERS R., BLEEKER M., VAN DE LEE T., HORNES M., FRIJTERS A., POT J., PELEMAN J., KUIPER M., ZAUBER M. 1995. AFLP: a new technique for DNA fingerprinting. Nucl. Acid Res. 23: 4407-4414.

ZHANG L.H., OZIAS-AKINS P., KOCHERT G., KRESOVICH S., DEAN R., HANNA W. 1999. Differentiation of bermudagrass (Cynodon spp.) genotypes by AFLP analyses. Theor. Appl. Genet. 98: 895-902.

ZUNIGA G.E., ALBERDI M., CORCUERA L.J. 1996. Nonstructural carbohydrates in Desv. from South Shetland Island, Maritime Antarctic. Environ. Experim. Bot. 33: 393-399.

ZWOLSKA I., RAKUSA-SUSZCZEWSKI S.J. 2002. Temperature as one of the environmental factors in the Arctowski Station Arez. Geograph. Pol. (in press). 